\title{
EX-Vivo Cardioprotective and Cytotoxic Screening of Fruits of Parmentiera cereifera Seem
}

\author{
Md. Reyad-ul-Ferdous ${ }^{1,2,3^{*}}$, Tamara Towshin Alam², Md. Atiqul Islam³, Md. Zahirul Islam Khan ${ }^{3}$, Fariha Tasnim², Md Eshak Khan ${ }^{3}$, Md Sharif \\ Ullah $^{3}$ and Tazmel Haque ${ }^{3}$
}

${ }^{1}$ Department of Pharmacy, Progati Medical Institute, Dhaka-1207, Bangladesh

${ }^{2}$ Department of Pharmacy, North South University, Dhaka-1229, Bangladesh

${ }^{3}$ Department of Pharmacy, State University of Bangladesh, Dhaka-1205, Bangladesh

\begin{abstract}
In this present investigation, the fruits extract of Parmentiera cereifera were subjected to a comparative evaluation of the cardio-protective activities and Cytotoxic to brine shrimps (Artemia salina) as compared with standard streptokinase (SK) and Vincristine sulphate (VS). The crude methanolic (ME) extract, Hexane (HXSF) soluble fraction, carbon tetrachloride (CTCSF) soluble fraction, the Aqueous (AQSF) and chloroform (CSF) soluble fraction fruits of $P$. cereifera were subjected to these studies. In thrombolytic study, the fruits extract crude methanolic (ME) extract and Hexane (HXSF) soluble fraction were demonstrated mild to moderate (2.5 to $21.50 \%$ ) thrombolytic activity in human blood specimen compared with standard streptokinase (SK) $66.77 \%$. The fruits extracts were demonstrated (1.78 to 79.90 ) significant Cytotoxic to $A$. salina with $\mathrm{LC}_{50}$ values ranging from 6.07 to $7.83 \mu \mathrm{g} / \mathrm{mL}$ compared with standard Vincristine sulphate (VS, $\mathrm{LC}_{50}$ value $0.45 \mu \mathrm{g} / \mathrm{mL}$ ).
\end{abstract}

\section{Keywords}

Parmentiera cereifera; Fruits extract; Cardio-protective activities; Cytotoxic screening

\section{Introduction}

Parmanteira cereifera (commonly-Candle tree) is a small tree with rough bark belonging to the family Bignoniaceae. The leaf is oblong and acuminate. The flowers are caulioflorous, nocturnal, white, slightly fragrant and spathaceous. The fruit and seeds of this tree are berry plate yellow, pendent, candel-like, smooth, edible and used as fodder source. The tree is native to pnama and cultivated for ornamental uses in many tropical countries. Previous studies demonstrate significant anti-inflammatory, cardioprotective, antimicrobial activity of leaves of $P$. cereifera. Several potential phytochemicals present in P. cereifera such as flavonoids, saponins, tannins, triterpenoids, steroids of leaves fraction [1]. Barks fraction contains flavonoids, saponins, triterpenoids, terpenoids [2]. Fruits fraction consists of flavonoids, saponins, tannins, triterpenoids, terpenoids, steroids [3]. As a part of our continuing studies on medicinal plants of Bangladesh, the organic soluble materials of fruits of $P$. cereifera were evaluated for thrombolysis, Cytotoxicity activity for the first time.

\section{Materials and Methods}

\section{Plant materials}

The fruits of $P$. cereifera were collected from Botanical garden, Mirpur, Dhaka, Bangladesh, in November 2011. A voucher specimen for this plant has been maintained in Bangladesh National Herbarium, Dhaka, Bangladesh (Accession no.36569). The sun dried and powdered fruits $(500 \mathrm{gm})$ of $P$. cereifera was macerated in $2.5 \mathrm{~L}$ of methanol for 7 days and then filtered through a cotton plug followed by Whatman filter paper number 1 . The extracts were concentrated with a rotary evaporator at low temperature $\left(40-45^{\circ} \mathrm{C}\right)$ and reduced pressure. The concentrated methanolic extracts (ME) were partitioned by modified Kupchan method [4] and the resultant partitionates which are pet-ether (PESF), carbon tetrachloride (CTCSF), chloroform (CSF), and aqueous (AQSF) soluble fractions were used for the experimental processes.

\section{Thrombolytic activity}

The thrombolytic activity was conducted for evaluation of cardioprotective drugs. The thrombolytic activity of all extracts was evaluated by the method developed by Daginawala et al., [5] and modified by Kawsar et al., [6] using streptokinase (SK) as the standard.

In short, the plant extract $(100 \mathrm{mg})$ suspended in $10 \mathrm{~mL}$ of distilled water was kept overnight. The soluble supernatant was decanted and filtered by using a $0.22 \mu$ syringe filter. For clot lysis, venous blood (500 $\mu \mathrm{L}$ ) drawn from human healthy volunteers was distributed in different sterile pre weighed microcentrifuge tube and incubated at $37^{\circ} \mathrm{C}$ for 45 minutes for clot formation.

After clot formation, the serum was completely removed without disturbing the clot and the clot weight was determined. $100 \mu \mathrm{L}$ aqueous solutions of different partitionates and crude extract were added separately to each microcentrifuge tube with the pre-weighed clot. Then, $100 \mu \mathrm{L}$ (30,000 I.U) of commercial streptokinase (SK) and 100mg of distilled water were separately added to the control tube as positive and negative controls, respectively.

All the tubes were then incubated at $37^{\circ} \mathrm{C}$ for 90 minutes and observed for clot lysis. After incubation, the released fluid was removed and tubes were reweighed to observe the difference in weight after clot disruption. Percentage of clot lysis was determined from below formula.

*Corresponding author: Md. Reyad-ul-Ferdous, Lecturer, Department of Pharmacy, Progati Medical Institute, Dhaka-1207, Bangladesh, Tel: +8801719134213; E-mail: rockyreyad@yahoo.com

Received September 22, 2014; Accepted October 28, 2014; Published November 04, 2014

Citation: Reyad-ul-Ferdous M, Alam TT, Islam MA, Khan MZI, Tasnim F, et a (2015) Ex-Vivo Cardioprotective and Cytotoxic Screening of Fruits of Parmentiera cereifera Seem. Biol Med (Aligarh) 7: 219. doi: 10.4172/0974-8369.1000219

Copyright: (c) 2015 Reyad-ul-Ferdous M, et al. This is an open-access article distributed under the terms of the Creative Commons Attribution License, which permits unrestricted use, distribution, and reproduction in any medium, provided the original author and source are credited. 


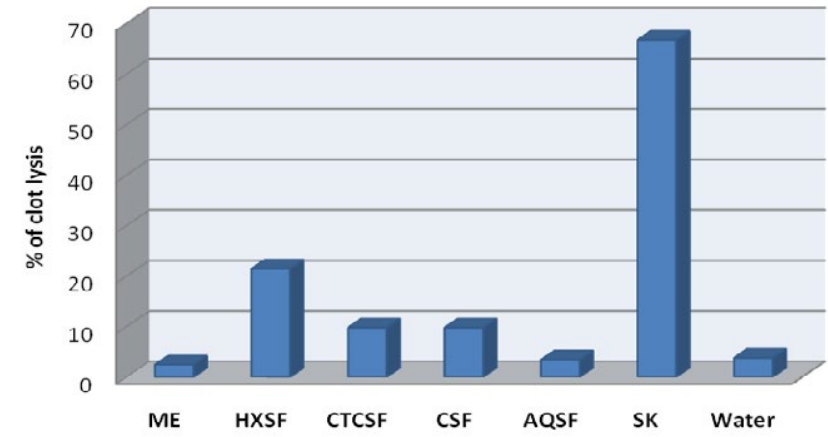

Figure 1: Thrombolytic activity of crude extract and different fractions of $P$ cereifera (ME $=$ Methanolic extract PESF $=$ Pet-ether soluble fraction; $\mathrm{CTCSF}=$ Carbon tetrachloride soluble fraction; $\mathrm{CSF}=$ chloroform soluble fraction; $\mathrm{AQSF}=$ Aqueous soluble fraction of the methanolic extract of $P$. cereifera. SK $=$ Streptokinase).

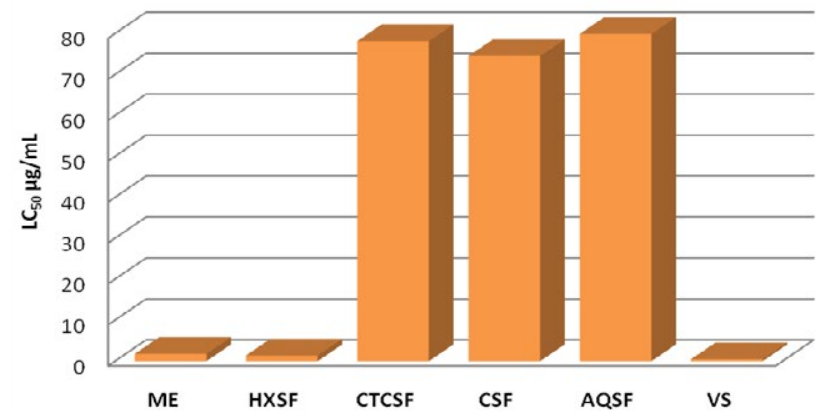

Figure 2: Brine shrimp Cytotoxic of crude extract and different fractions of $P$. cereifera (VS $=$ Vincristine sulphate; $\mathrm{ME}=$ Methanolic extract; $\mathrm{PESF}=$ Pet-ether soluble fraction; $\mathrm{CTCSF}=$ Carbon tetrachloride soluble fraction; $\mathrm{CSF}=$ chloroform soluble fraction; $A Q S F=$ Aqueous soluble fraction of the methanol extract of $P$. cereifera).

$\%$ of clot lysis $=($ weight of released clot $/$ clot weight $) \times 100$

\section{Cytotoxic screening}

The Cytotoxic screening was conducted by Brine shrimp lethality bioassay. This technique was applied for the determination of general toxic property of the DMSO solutions of plant extractives [7,8] against Artemia salina in a 1-day in vivo assay. Vincristine sulphate was used as positive control.

For the experiment, different concentrations (400-0.781 $\mu \mathrm{g} /$ $\mathrm{mL}$ ) of methanol extract and its carbon tetrachloride, petroleum ether, chloroform and aqueous soluble fractions were prepared in DMSO. General toxic property of the plant extract and its different fractions against Artemia salina was determined in a 1-day in vivo assay. Vincristine sulphate was used as positive control. The mortality percentage and $\mathrm{LC}_{50}$ (lethal concentration for $50 \%$ of the population) were determined using statistical analysis and the graph plotted concentration against percent lethality.

\section{Statistical Analysis}

All results were expressed as the mean \pm standard deviation (SD).

\section{Results and Discussion}

As a part of discovery of cardio protective drugs from natural resources the extractives of Candle tree $(P$. cereifera) were assessed for thrombolytic activity and the results are presented in (Figure 1). Addition of $100 \mu \mathrm{L} \mathrm{SK}$, a positive control (30,000 I.U.), to the clots and subsequent incubation for 90 minutes at $37^{\circ} \mathrm{C}$, showed $66.77 \%$ lysis of clot. On the other hand, distilled water was treated as negative control $(3.87 \%)$ of lysis of clot. In this study, the fruits extracts were demonstrated moderate activity ranging from (3.5\% to $21.50 \%$ ). The Hexane (HXSF) soluble fraction exhibited highest thrombolytic activity $(21.50 \%)$ showed in the figure- 1 . The thrombolytic activity is demonstrate due to the presence of plant's diverse composition like flavonoids, tannins and terpenoids [9].

The fruits extracts were demonstrated ranging from (1.78-79.90) significant Cytotoxic to $\mathrm{A}$. salina with $\mathrm{LC}_{50}$ values ranging from (6.07$7.83) \mu \mathrm{g} / \mathrm{mL}$ as compared to standard Vincristine sulphate ( $\mathrm{LC}_{50}$ value $0.45 \mu \mathrm{g} / \mathrm{mL}$ ). The results are given in Figure 2 .

The brine shrimp test represents a simple, rapid and inexpensive bioassay for testing plant extract lethality which in most cases has a good correlation with cytotoxic and anti-tumour properties $[10,11]$. Crude extracts resulting in $\mathrm{LC}_{50}$ values of less than $250 \mu \mathrm{g} / \mathrm{mL}$ is usually considered significantly active and potential for further investigation [12]. The result obtained from the brine shrimp lethality bioassay of $P$. cereifera can serve as a guide for the isolation of cytotoxic compounds from the methanol extract and different fractions of the plant by using more specific and more sophisticated bioassays.

\section{Conclusion}

Results of the present investigation for the first time indicate that the $P$. cereifera fruits possess significant cardio-protective and cytotoxic activities and suggest that the plant may be a safe, economical and easily available source of natural agents used in cardiovascular disorders involving blood clot and anticancer agents due to mild toxic effect. These activities may occur due to the presence of both types of active lead compounds in different fraction of this plant fruit extracts. Those compounds may responsible for cardio-protective and anticancer activities. Further investigation on identification, isolation and purification of active moieties of the plant responsible for these therapeutic properties may lead to new drug development.

\section{Acknowledgement}

We are acknowledge to Progati Medical Institute for provide us required facilities to complete this work.

\section{References}

1. Reyad-ul-Ferdous, Ridwan Bin Rashid Md, Al Amin Sikder, Fahima Akta Md and Mohammad A. Rashid (2012) Preliminary In Vitro Biological and Phytochemical Screenings of Parmentiera cereifera Seem. Bangladesh Pharmaceutical Journal 15: 103-106.

2. Reyad-ul-ferdous Md, Asif Hassan Md, Nawfel Abdullah, Mridul sarker, Faizul Hafiz, et al. (2014) Preliminary in Vitro Phytochemical Screenings of the Barks of Parmentiera cereifera Seem. Int J Innov and App Res 2: 57- 60.

3. Reyad-ul-ferdous Md, Anisul Islam Md, Fariha Tasnim, Nawfel Abdullah Tamara Towshin Alam, et al. (2014) Qualitative Phytochemical Screenings of Methanolic Extract of P. cereifera Seem Fruits. UK J Pharm and Biosc 2: 22-23.

4. Van Wagenen BC, Larsen R, Cardellina JH, Ran dazzo D, Lidert ZC, et al. (1993) A potent insecticide from the sponge Ulosaruetzleri. J Org Chem 58: 335-337.

5. Prasad S, Kashyap RS, Deopujari JY, Purohit HJ, Daginawala HF, et al. (2006) Development of an in vitro model to study clot lysis activity of thrombolytic drugs. Thromb J 4: 14

6. Kawsar MH, Sikder MA, Rana MS, Nimmi I, Rashid MA (2011) Studies of Thrombolytic and cytotoxic properties of two asteraceous plants of Bangladesh. Bangladesh Pharmaceutical Journal 14: 103-106. 
Citation: Reyad-ul-Ferdous M, Alam TT, Islam MA, Khan MZI, Tasnim F, et al (2015) Ex-Vivo Cardioprotective and Cytotoxic Screening of Fruits of Parmentiera cereifera Seem. Biol Med (Aligarh) 7: 219. doi: 10.4172/0974-8369.1000219

Page 3 of 3

7. Meyer BN, Ferrigni NR, Putnam JE, Jacobsen JB, Nicholsand DE, et al. (1982) Brine shrimp: a convenient general bioassay for active plant constituents. Planta Med 45: 31-34.

8. McLaughlin JL, Anderson JE, Rogers LL (1998) The use of biological assays to evaluate botanicals. Drug Infor J 32: 513-524.

9. Dwivedi S (2007) Terminalia arjuna Wight \& Arn.--a useful drug for cardiovascular disorders. J Ethnopharmacol 114: 114-129.
10. McLaughlin JL (1991) Methods Plant Biochem 6: 1-32.

11. Mclaughlin JL, Rogers LL, Anderson (1998) EJ. Drug Info J 32: 513-524.

12. Rieser MJ1, Gu ZM, Fang XP, Zeng L, Wood KV, et al. (1996) Five nove mono-tetrahydrofuran ring acetogenins from the seeds of Annona muricata. $J$ Nat Prod 59: 100-108. 